\title{
THERE ARE NO PRECONDITIONS FOR THE INVESTMENT GROWTH IN RUSSIA B. Taganov
}

In the short term, Russia will have low investment activity both on the part of foreign and domestic investors due to the low quality of the institutional environment and high risks. Analysis of various indices movement demonstrates that so far there are no preconditions for wide scale private investment in Russia. Safeguarding of the total inviolability of property rights represents major precondition for the improvement of the investment climate in Russia. This basic for the civilized societies in the $21^{\text {st }}$ century condition would have improved the investment climate in the country and would have put Russia on the path of long-term economic growth.

The macroeconomic situation in the Russian Federation continues to deteriorate. At end-2015, the index of industrial production in Russia fell by $3.4 \%$ in comparison with the corresponding period of $2014^{1}$. At end-2016 Q1, index of industrial production in Russia declined compared to Q1 2015 by $0.6 \%$. Calendar and seasonal adjustment of the index of industrial production indicates that the growth rates of the Russian economy as of Q1 2016 stay at zero level'.

Analysis of the breakdown of investment in fixed assets across the sources of financing shows that at end-2015, budget investment in the nominal terms decreased by $3.5 \%$ and own and borrowed funds declined by $1.0 \%$ in comparison with the same period of $2014^{3}$. Taking into consideration the inflation rates, such reduction of investment in the nominal terms means that in real terms budget investment at year-end 2015 contracted still more - by $16.5 \%$, and own and borrowed investment fell by $14.3 \%$ in comparison with 2014 (Fig. 1).

At present, Russian experts are discussing the ways of improving the investment climate and the

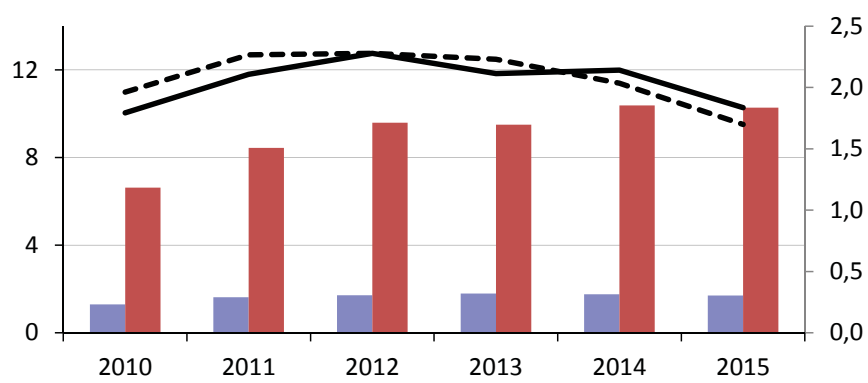

Budget investment in nominal terms ( $R b$ trillion (left scale)

Own and borrowed investment in nominal terms ( $\mathrm{Rb}$ trillion (left scale)

- Volume index of own and borrowed investment in real terms (right scale), base year 2010

- - Volume index of budget investment in real terms (right scale) base year $2010(2010=100)$

Sources: own calculations on Rosstat data, World Bank.

Fig. 1. Movement of fixed investment across sources of financing in nominal terms ( $R b$ trillion) and volume index of investment across sources of financing in real terms (base year $2010=100$ )

1 According to the data released by Rosstat, the index of industrial production in percent to the previous year: http://www.gks.ru/bgd/free/b00_24/IssWWW.exe/Stg/d000/I001700R.HTM 2 Idrisov G, Kaukin A. Russian industry in Q1 2016: the onset of stagnation? OMREO No.7 (25) 2016.

3 According to the data released by Rosstat, investment in fixed capital in the Russian Federation across the sources of financing: http://www.gks.ru/free_doc/new_site/business/ invest/Inv-if.xls 
instance, in the framework of the Economic Council under the RF President representatives of the executive branch of power propose to reduce the costs for economic agents first of all by way of restricting tariffs of monopolies and reduction of administrative costs incurred by businesses ${ }^{1}$. Other member of the Economic Council consider that in the first place it is necessary to regain the trust of businesses in the government ${ }^{2}$. Members of the Stolypin Club, whose program is being also discussed at the Council, favor emission of currency, reduction of the key rate, and granting of tax privileges ${ }^{3}$. The Center for Strategic Studies is proposing an implementation of structural reforms ${ }^{4}$. In the framework of the panel discussion at the $20^{\text {th }}$ St. Petersburg International Economic Forum, which was dedicated to the issue of domestic investment, the panelists named the lack of optimism seen in the business community, as well as low quality of the justice and law enforcement systems as one of major reasons for the unfavorable investment environment seen in Russia ${ }^{5}$.

Bodies of executive authorities of Russia are working on the improvement of the analytical instruments used for the monitoring of the state of the investment climate. For example, in April 2016, the Government of Russia approved a list of indices used for the calculation of a national rating of the state of the investment environment in the subjects of the Russian Federation ${ }^{6}$. At the same time, the document does not mention issues related to securing the investors' rights, as well as mechanisms of the implementation of investments as a whole. In addition, there is a lot of room of improvement regarding the list. It can be done by way of incorporation of principal criteria, which the investors use to assess the risks.

Overall, while analyzing the Russian economy as of Q2 2016, Oleg Zamulin has expressed a consensus opinion regarding the state of affairs: "The recession in the Russian economy, to a large extent is connected with the supply side, and not with the demand side." ${ }^{7}$ In such a situation, precisely invest-

1 Vedomosti, Alexei Ulyukaev submitted the plan of Russia's investment growth: http:// www.vedomosti.ru/economics/articles/2016/04/27/639279-aleksei-ulyukaev-predstavilinvestitsionnogo-rosta-rossii

2 Vedomosti, Andrei Klepach: "Not only money is needed, businesses' trust in the government

is required": http://www.vedomosti.ru/economics/characters/2016/05/16/641089-proigraem-dazhe-ukraine

3 The Stolypin Club, Program "Economics of Growth": http://stolypinsky.club/economicarosta/

4 Vedomosti, Alexei Kudrin will submit to the President a reform of courts, law enforcement agencies, and the budget: http://www.vedomosti.ru/economics/articles/2016/05/23/641940kudrin-predlozhit-prezidentu-reformu-sudov-pravoohranitelnoi-sistemi-byudzhetnuyu-konsolidatsiyu

5 SPIEF, Domestic investments - source of a new economic growth: https://forumspb.com/ $\mathrm{ru} / 2016 /$ sections/22/materials/196/news/563

6 On the approval of the list of indices for the calculation of the national rating of the investment climate state in the subjects of the Russian Federation: http://government.ru/ docs/22599/

7 Oleg Zamulin. Russia in 2015: recession on part of supply. NEA journal, No. 1 (29), 2016, pp. 181-185. Nevertheless, it should be noted, that Zamulin's arguments given in its favor are built on the lack of the unemployment hike in Russia. Undoubtedly, the official data on unemployment indicated precisely this. At the same time, there is evidence that the unemployment hike is suppressed by such measures as transfer of the workers to port time working day (with corresponding reduction of wages) and sending worker to leave without pay, which contributes to a reduction of aggregate demand.

For example, the number of workers working on part time scheme at the employers' initiative in Russia in Q1 2016 constituted 142,100 individuals, which is by 12,500 individuals more that in the corresponding period of 2015. See Rosstat, Number of workers on payroll who work 
ments allocated in the new capacities and improvement of the investment attractiveness are high priority goals.

\section{Entrepreneurial confidence and institutional environment}

The business confidence index in Russia, which characterizes aggregate expectations of entrepreneurs in different sectors year after year remains constantly negative. ${ }^{1}$ The growth number of criminal suits filed on economic articles (in 2015 their number went up by $22 \%$ in comparison with 2014 ). ${ }^{2}$ As of March 2016, barely $9 \%$ of chief executive officers in mining and quarrying sector considered favorable economic situation in their organization and $6 \%$ of CEOs in the manufacturing sector. ${ }^{3}$

Taking into consideration the risk level and the key interest rate in Russia, the expected investment projects' return should stay at the level of $20 \%{ }^{4}$ However, securing of such level of return does not ensure the investment inflow including due to sovereign risks. For example, an attempt made by the RF Finance Ministry to float Eurobonds to the tune of $\$ 3 \mathrm{bn}$, which was rejected by the majority of international banks ${ }^{5}$ owing to potential possibility that the assets can reach organizations included in various sanction lists. Outflow of assets from the funds pointed to the Russian shares market represents market's unfavorable assessment of Russia's investment attractiveness. At end-2016 Q1, the outflow came to \$336.3 $\mathrm{mn} .{ }^{6}$

In recent years the priorities of the Russian federal budget are shifted towards non-production spending, meanwhile investment in human capital is contracting. ${ }^{7}$ Meanwhile, inflow of investment and expansion of economic capacities are closely linked with the availability of high-grade human capital as one of the paramount components of endogenous economic growth. ${ }^{8}$ In

part time across subjects of the Russian Federation: http://www.gks.ru/free_doc/new_site/ population/trud/nz_sub.xisx

1 According to Rosstat data, business activity of organizations in Russia in March 2016: http://www.gks.ru/bgd/free/B04_03/lssWWW.exe/Stg/d06/59.htm

2 RBC: http://www.rbc.ru/rbcfreenews/56efd54a9a7947476789caf2

3 According to data released by Rosstat, business activity of organizations seen in Russia in March 2016: http://www.gks.ru/bgd/free/B04_03/IssWWW.exe/Stg/d06/59.htm

4 We are parting from the fact that risk-free rate in rubles in Russia as of Q2 2016 stays at $10 \%$ (http://www.rusbonds.ru/cmngos.asp), where it should be added $10 \%$ equity risk premium, calculated Damodaran: http://www.stern.nyu.edu/ adamodar/pc/datasets/ctryprem.xls. To note, that such estimate of expected return correlates with the estimate of expected return made by AFK 'Systema' President Shamolin. He cited it at the 20th St. Petersburg International Economic Forum: https://forumspb.com/ru/2016/sections/22/materials/196/news/563

5 Vedomosti, Major western banks have refused to float Russian Eurobonds: https://www. vedomosti.ru/economics/articles/2016/03/25/635078-velika-rossiya-prodavat-nekomu

6 Gorbatikov E., Khudko E. Financial Markets. Russian Economic Developments. No. 3 March-April 2016.

7 Breakdown of spending on production expenses and non-production expenses is consistent with the IMF, World Bank, and OECD classification. Production expenses include expenses on education (associated with growing human capital), R\&D (secure growth via innovations and technological progress expressed in productivity growth), in infrastructure, transport and communications (contribute to increasing productivity of private capital) and on health care (owing to improves health of the population, the number of employed grow together with labor productivity). Non-production expenses (but, of course, needed to a certain extent) are expenses on public administration, law enforcement, national economy and defense (such expenses do not result in creation of production capacities; there is a direct diversion of resources from other sectors of the economy).

8 See, for example, Acemoglu, D. (2008). Introduction to modern economic growth. Princeton University Press. Noorbakhsh, F., Paloni, A., \& Youssef, A. (2001). Human capital 
medium term, the current pattern of the federal budget expenditure hampers the creation of favorable conditions for the inflow of investment (both domestic and international).

As of Q2 2016, we should note the excessive participation of the state in the economy (8 out of 10 major Russian enterprises based on annualized income are state owned ${ }^{1}$, and $71 \%$ of GDP is produced by the state $\left.{ }^{2}\right)$. Privatization of large state assets so far remains in the inactive state ${ }^{3}$. Current low prices on Russian assets are named as one of the reasons. To note, the economic science indicates that the price on saleable asset can be raised by way of admitting to the tender the maximum number of participants ${ }^{4}$. Moreover, on its own privatization is not an instrument for the budget replenishment (although it is obvious that the higher the price of the asset the better for the state and society). External economies are important in privatization, which affect the economic system as a whole: increased total factor productivity and expansion of production capacities, which ensure long-term economic growth, more efficient corporate governance, rational distribution of resources in the economy, and expansion of limits for private initiative ${ }^{5}$.

\section{International assessments of Russia's investment attractiveness}

According to the index of investment freedom, which is calculated by the Heritage foundation and reflects presence or lack of restrictions for investors in business activity in a country (index stays at 0 in the event of total ban on foreign investment, to 100 in the event of 'ideal' conditions for investment). At year-end 2015, Russia's rating is 25 , which is below the average world level (58), average European level (74.1), and even levels of Nigeria (40) and China (30). Heritage Foundation 2015 Final Report notes "Russia's prospects for long-term, diversified, sustainable economic growth remain bleak. There is no efficiently functioning legal framework, and government continues to interfere in the private sector through myriad state-owned enterprises." ${ }^{6}$

Doing business Index calculated by the World Bank (in 2012 the President of Russia stated as a priority improvement of Russia's ranking) ${ }^{7}$ ranked Russia $51^{\text {st }}$

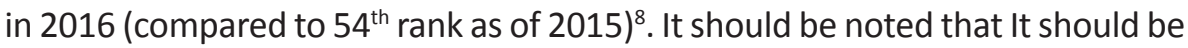
noted that a general country's ranking along this index is calculated on indices posted by one city, which according to methodology is the "economy's largest

and FDI inflows to developing countries: New empirical evidence. World development, 29(9), 1593-1610.

1 Kowalski, P, M Büge, M. Sztajerowska, and M. Egeland (2013), "State-Owned Enterprises: Trade Effects and Policy Implications", OECD Trade Policy Paper, No.147, OECD Publishing.

2 Russian Federation: Fiscal Transparency Evaluation. International Monetary Fund, 2014.

3 RBC. Privatization under threat: why the authorities are not in a hurry to sell assets: http://www.rbc.ru/business/21/04/2016/56f3dfca9a7947f3cc861fa3?from=rbc_choice

4 Brannman, L., Klein, J. D., \& Weiss, L. W. (1987). The price effects of increased competition in auction markets. The Review of Economics and Statistics, pp. 24-32.

5 Brown, J. D., Earle, J. S., \& Telegdy, A. (2006). The productivity effects of privatization: Longitudinal estimates from Hungary, Romania, Russia, and Ukraine. Journal of Political Economy, 114(1), pp. 61-99.

6 The Heritage Foundation, 2016 Index of Economic Freedom: http://www.heritage.org/ index/pdf/2016/book/index_2016.pdf

7 The RF President's Decree of 7 May 2012, No. 596 "On long-term state economics." One of the assignments of the Decree was upgrading of Russia's ranking in the World Bank Doing business ranking from 120 place seen in 2011 to 50 th in 2015, and to 20th in 20188. http:// rg.ru/2012/05/09/gospolitika-dok.html

8 Ease of Doing Business in Russian Federation: http://www.doingbusiness.org/data/exploreeconomies/russia 
business city). In case of Russia, Moscow is the largest business center of the country. In other words, in essence, Russia's resulting aggregate indicator in "Doing business" ranking reflects the level of the ease doing business solely in the capital. At the same time, Moscow is not the leader regarding indices of the ease of doing business and even of the contrary. In subnational research conducted by the World Bank and International Financial Corporation "Doing business in Russia", Moscow takes the last place in the aggregate ranking of doing business; meanwhile best practices in doing business are spread across various regions of the country. The implementation of best regional practices in Moscow will contribute to significantly fare better in the ranking "Doing business". In particular, in order to achieve this goal, the Moscow authorities need to adopt practices of St. Petersburg, Volgograd, and Ulyanovsk regarding registration of enterprises, practice of Surgut, Stavropol, and Kaliningrad regarding construction permits, practice of Saransk, Vladikavkaz, and Rostov-onDon regarding getting electricity by legal entities, as well as practice of Kaluga, Vladikavkaz, and Vladivostok regarding registering property. Such activity will be obviously helpful to entrepreneurs working in Moscow, but not being a systemic one will not improve the business climate in Russia as a whole.

According to 2015 Country Attractiveness Index for investors in venture capital and private equity limited partnerships calculated by International Center for Financial Research of the Business School of the University of Navarra, Russia is ranked $39^{\text {th }}$ (out of 129) between Colombia (38) and Mexico (40), which means that investment flow in Russia are subject to significant country risks. At the same time, all BRIC members, except Brazil, stay above Russia: China ranked 21th, India $-29^{\text {th }}$, and South Africa $-37^{\text {th } 1}$.

According to the Ernst \& Young European investment attractiveness sur$v^{v^{2}}{ }^{2}$, Russia is less and less attractive country for foreign investment. For example, in 2015 , Russia's investment attractiveness fell by $8 \%$ compared to 2014 , and by $10 \%$ in comparison with 2008 . Such reduction will result in the lack of new jobs in Russia (only in 2014, owing to foreign investment Russia posted around 20,000 new jobs), and therefore contraction of mid-term GDP growth rates. The survey names growing sovereign risks and deterioration of the institutional environment as the main reasons for reduction of Russia's investment attractiveness.

\section{International formula for the improvement of the investment climate}

Several international organizations (OECD, the World Bank, and the IMF) offer general concepts and formulae aimed at improving the investment climate in the developing countries (they include reduction of the state participation in the economy, securing free trade and capital flow, decrease of regulatory pressure on the economy, securing property rights, etc.) $)^{3}$. Although

1 The Venture Capital \& Private Equity Country Attractiveness Index: http://blog.iese.edu/ vcpeindex/

2 EY's attractiveness survey Europe 2015: http://www.ey.com/Publication/vwLUAssets/ EY-european-attractiveness-survey-2015/\$FILE/EY-european-attractiveness-survey-2015.pdf 3 Indicated organizations develop instructions for the attraction of investment (see URL: https://www.wbginvestmentclimate.org/toolkits/investmentgeneration-toolkit/), and release various analytical materials with economic policy proposals on improving the investment climate and attracting FDI for the developing countries, see, for example: Arbatli, E. Economic policies and FDI inflows to emerging market economies. International Monetary Fund, 2011, p. 26; Bellak, C., Leibrecht, M., Stehrer, R. Policies to Attract FDI: an Industry-level Analysis. OECD Investment Division, 2008, p. 33. 
each country has its own features, on the whole framework proposals serve as a base for the development of national programs aimed at improving the investment climate and attract investment.

Economists also offer various formulae aimed at securing economic growth, which take into consideration each country's specifics. For example, the paper written by Ricardo Hausmann, Dani Rodrick, and Andres Velasco highlight three major issues, which a country can face: large costs of investment attraction, low return from the economic activity ${ }^{1}$. The authors maintain that purposeful elimination of the paramount problem in the economy will bring the highest result for economic growth. Although some experts applied methodology of Hausmann, Rodrick, and Velasco to the analysis of the Russian economy as well as to the analysis of other economies ${ }^{2}$, the methodology failed to be widely disseminated for a score of reasons. Firstly, many economists put into question the logic of Hausmann, Rodrick, and Velasco method. For example, Jeffrey Sacks states that the majority of developing economies are so unbalanced that marginal improvement in the most problem area will not significantly affect the economic growth. In these cases, decisive measures are required across multiple areas, rather than in one most problematic one ${ }^{3}$. Secondly, in practice growth diagnostics according to the methodology of Hausmann, Rodrick, and Velasco is extremely difficult, hence often does not seem possible to reveal most problematic sphere in the developing economy ${ }^{4}$, which is consistent with comments made by Rodriquez ${ }^{5}$, Russian experts, in their turn, propose such measures for the improvement of the business climate in Russia, which include war on corruption, securing property rights and independence of courts, and reducing administrative barriers ${ }^{6}$.

\section{Ways of improving the investment climate in Russia}

While analyzing the short-term future of the improvement of the investment climate, one can regret the lack of fundamental positive shifts. Implementation of structural reforms (until at least the end of 2018) is seen unlikely because any reforms are associated with considerable risks of losing public support in the short-term.

Allocation of resources in the resolution of issues with high benefit/cost ratio will contribute to the improvement of the investment climate and

1 Hausmann, R., Rodrik, D., \& Velasco, A. (2008). Growth diagnostics. The Washington consensus reconsidered: Towards a new global governance, pp. 324-355.

2 See M. Atnashev. (2016) Adequacy testTect or why Rudrin won't help. https://slon.ru/ posts/66902. Hausmann, R., \& Klinger, B. (2008). Growth Diagnostic: Peru. Inter-American Development Bank. Qayyum, A., Khawaja, I., \& Hyder, A. (2008). Growth diagnostics in Pakistan. European Journal of Scientific Research, 24(3), pp. 433-450.

3 Habermann, H., \& Padrutt, P. (2011). Growth Diagnostics: Strengths and Weaknesses of a Creative Analytical Framework to Identify Economic Growth Constraints in Developing Countries. Journal of Knowledge Management, Economics and Information Technology, 1(7).

4 See, for example, Calvo, S. (2006). Applying the growth diagnostics approach: the case of Bolivia. The World Bank.

5 Rodriguez, F. (2005). Comments on Hausmann and Rodrik. Economia, 6(1), pp. 88-98. $\mathrm{http}$ ://frrodriguez.web.wesleyan.edu/docs/academic_english/comments_hausmann_rodrik. pdf

6 See, for example, Glukhova M. (2016) Investment Climate: whu positive shifts in global ratings will not affect firms' general state? Dispute-Club ARETT: http://www.arett.ru/.files/74/ file/Presentations\%202016-04-21.rar

Yakovlev A. (2016). What is missing in the current investment climate rankings for adequate reflection of reality? Dispute-Club ARETT: http://www.arett.ru/.files/74/file/Presentations\%20 2016-04-21.rar 
Russia's economic situation as a whole ${ }^{1}$. Among these are, for example, issues mentioned by Adam Smith ${ }^{2}$, ensuring free trade in order to obtain benefits from it (for instance, lifting food sanctions, which speed up inflation amid contraction of disposable income of the population, thus reducing overall demand $^{3}$ ) and cutting targeted support of certain enterprises in different sectors. The government ought to review practice of its participation in competitive sectors of the economy.

Taking into account the mechanism of investment decision by economic agents, the government ought to reject "hand control" of the tax burden on business (for example, from granting tax holidays) in favor of general reduction of risks of doing business in Russia. Risks of the successful implementation of the investment project affect project economics more significantly than tax rates. It is due to the fact that while estimating volumes of financial flow probability of project success is multiplied by the overall volume of profit and tax rate at best will affect just its part (profit, value added, payroll, etc.). Thus, reduction by 1 p.p. of probability of successful project implementation. In other words, getting all the profit as a whole affects the project in a more significant way than a reduction by 1 p.p. of any tax rate ${ }^{4}$.

On the whole, overall secure of property rights remains the paramount precondition for the improvement of the investment climate in Russia. This basic for civilized societies in $21^{\text {st }}$ century condition would have improved the investment climate of the country and would have placed Russia on the path of long-term sustainable economic development.

1 W. Easterly. (2016) The Tyranny of Experts. Economists, Dictators, and the Forgotten Rights of the Poor. Gaidar Institute Publishers (in Russian), 2016.

2 A. Smith. (2015). An Inquiry into the Nature and Causes of the Wealth of Nations. Litres. 3 According to Bank of Russia, sanctions just against Turkey can result in additional inflation of $0.4 \%$ per annum. Overall food embargo, according to different estimates, will add $3 \%$ of additional inflation per annum. At the same time, food embargo does not significantly harm countries, against which it is imposed. According to Austrian Institute of Economic Research (WIFO), As a result of Russian "countersanctions" unemployment in EU and Switzerland can growth at worst by just $1 \%$ (in long term) and the value increase shortfall in income can increase by not more than $0.8 \%$ of the total EU and Switzerland GDP.

See. Disrupted Trade Relations Between the EU and Russia: The Potential Economic Consequences for the EU and Switzerland: http://www.wifo.ac.at/jart/prj3/wifo/resources/ person_dokument/person_dokument.jart?publikationsid=58220\&mime_type=application/pdf 4 See in detail: G Idrisov, B. Taganov. (2015) Attracting FDI to accelerate growth. Is it worth reconsidering? Russian Foreign Economic Bulletin, 2015(1). 